\title{
Chromate Reduction by Cell-Free Extract of Bacillus firmus KUCr1
}

\author{
GOPI BALLAV SAU, SWAGATA CHATTERJEE and SAMIR KUMAR MUKHERJEE*
}

Department of Microbiology, University of Kalyani, Kalyani 741235, India

Received 9 February 2010, revised 10 June 2010, accepted 20 June 2010

\begin{abstract}
Microbial enzymatic reduction of a toxic form of chromium [Cr(VI)] has been considered as an effective method for bioremediation of this metal. This study reports on the in vitro reduction of $\mathrm{Cr}(\mathrm{VI})$ using cell-free extracts from a $\mathrm{Cr}(\mathrm{VI})$ reducing Bacillus firmus $\mathrm{KUCr} 1$ strain. Chromium reductase was found to be constitutive and its activity was observed both in soluble cell fractions $\left(\mathrm{S}_{12}\right.$ and $\left.\mathrm{S}_{150}\right)$ and membrane cell fraction $\left(\mathrm{P}_{150}\right)$. The reductase activity of $\mathrm{S}_{12}$ fraction was found to be optimal at $40 \mu \mathrm{M} \mathrm{Cr}(\mathrm{VI})$ with enzyme concentration equivalent to $0.493 \mathrm{mg}$ protein $/ \mathrm{ml}$. Enzyme activity was dependent on NADH or NADPH as electron donor; optimal temperature and $\mathrm{pH}$ for better enzyme activity were $70^{\circ} \mathrm{C}$ and 5.6 , respectively. The $\mathrm{K}_{\mathrm{m}}$ value of the reductase was $58.33 \mu \mathrm{M}$ chromate having a $\mathrm{V}_{\max }$ of $11.42 \mu \mathrm{M} / \mathrm{min} / \mathrm{mg}$ protein. The metabolic inhibitor like sodium azide inhibited reductase activity of membrane fraction of the cell-free extract. Metal ions like $\mathrm{Cu}^{2+}, \mathrm{Co}^{2+}, \mathrm{Ni}^{2+}$ and $\mathrm{As}^{3+}$ stimulated the enzyme but others, such as $\mathrm{Ag}^{+}, \mathrm{Hg}^{2+}, \mathrm{Zn}^{2+}, \mathrm{Mn}^{2+}, \mathrm{Cd}^{2+}$ and $\mathrm{Pb}^{2+}$, inhibited $\mathrm{Cr}(\mathrm{VI})$ reductase activity.
\end{abstract}

K e y w ord s: Bacillus firmus, cell-free extract, chromium reductase

\section{Introduction}

Application of Cr-resistant bacteria to detoxify $\mathrm{Cr}(\mathrm{VI})$ has been considered as an effective bioremediation method (Ohtake and Silver, 1994; Shakoori et al., 1999; Ganguli and Tripathi, 2002; Cheung and Gu, 2007; Sau et al., 2008). Bioremediation of Cr(VI) can occur by enzymatic reduction of $\mathrm{Cr}(\mathrm{VI})$ to $\mathrm{Cr}(\mathrm{III})$ via $\mathrm{Cr}(\mathrm{V})$ and $\mathrm{Cr}(\mathrm{IV})$ intermediates (Camargo et al., 2003; Xu et al., 2004; Xu et al., 2005; Pal et al., 2005; Cheung et al., 2006) or through immobilization (Losi et al., 1994). In the course of aerobic reduction, the cytosolic fractions of most chromium resistant bacteria exhibit $\mathrm{Cr}(\mathrm{VI})$ reductase activity (Campos et al., 1995; Cervantes et al., 2001), while under anaerobic conditions, $\mathrm{CrO}_{4}{ }^{2-}$ is used as a terminal electron acceptor and is reduced in the cell membrane (McLean and Beveridge, 2001).

Requirement of electron supply is obvious during the reaction process, considering the process a redox reaction. The enzyme responsible for $\mathrm{Cr}(\mathrm{VI})$ reduction has not yet been well characterized, though there are reports on reduction kinetics of $\mathrm{Cr}(\mathrm{VI})$ reduction by cell-free extracts (CFE) with varied results (Ishibashi et al., 1990; Suzuki et al., 1992; McLean and Beveridge, 2001; Park et al., 2000; Camargo et al.,
2003; Pal et al., 2005). Studies using partially purified $\mathrm{Cr}(\mathrm{VI})$ reductase from Pseudomonas ambigua G-1 (Suzuki et al., 1992) and P. putida MK1 (Park et al., 2000) have indicated $\mathrm{Cr}(\mathrm{VI})$ reduction using NADH or NADPH as a source of electrons. In Bacillus sp. ES29, $\mathrm{Cr}(\mathrm{VI})$ reductase was found in the soluble fraction of CFE, which utilizes NADH as electron donor (Camargo et al., 2003).

$\mathrm{Cr}(\mathrm{VI})$ reducing Bacillus firmus $\mathrm{KUCr} 1$ has been reported and its potential to reduce $\mathrm{Cr}(\mathrm{VI})$ using whole cells under culture condition was documented earlier (Sau et al., 2008). This study reports on the reduction of $\mathrm{Cr}(\mathrm{VI})$ by CFE of this strain, effects of different electron donors, metal ions, inhibitors, $\mathrm{pH}$ and temperature on its $\mathrm{Cr}(\mathrm{VI})$ reducing activity, and cellular localization of $\mathrm{Cr}(\mathrm{VI})$ reductase.

\section{Experimental}

\section{Materials and Methods}

Microorganism and growth condition. $\mathrm{A} \mathrm{Cr}(\mathrm{VI})$ resistant Bacillus firmus KUCr1 (NCBI GenBank 16S rDNA sequence Accession No EU784699) was earlier reported (Sau et al., 2008) and used in this study.

* Corresponding author: S.K. Mukherjee, Department of Microbiology, University of Kalyani, Kalyani 741235, India; phone: (+91) 3325827315; fax: (+91) 3325828282; e-mail: dr.samirmukherjee@klyuniv.ac.in 
Cells were grown aerobically in PYG medium (peptone $10 \mathrm{~g} / \mathrm{l}$; yeast extract $5 \mathrm{~g} / \mathrm{l}$; glucose $3 \mathrm{~g} / 1$; $\mathrm{pH}$ 7.2) supplemented with or without (control) $0.1 \mathrm{mM} \mathrm{Cr}(\mathrm{VI})$ as $\mathrm{K}_{2} \mathrm{CrO}_{4}$ under continuous shaking on a rotary shaker at $35^{\circ} \mathrm{C}$ for $24 \mathrm{~h}$.

Preparation of cell-free extract (CFE) and cellular fractions. Cell-free extract (CFE) and cellular fractions were prepared following McLean and Beveridge (2001) with little modification. Cells grown in PYG medium were harvested at the exponential phase, washed three times in $0.2 \mathrm{M}$ phosphate buffer ( $\mathrm{pH} 7.2)$ by centrifugation $\left(4000 \times \mathrm{g}\right.$ at $\left.4^{\circ} \mathrm{C}\right)$, resuspended in the same buffer to have a $10 \mathrm{ml}$ suspension and kept in an ice bath. Cells were disrupted with an ultrasonicator (Hielscher Ultrasound Technology, UP50H). Power was applied five times in $1 \mathrm{~min}$ pulses with $100 \%$ amplitude. After sonication the suspension was centrifuged at $12000 \times \mathrm{g}$ for $10 \mathrm{~min}$ at $4^{\circ} \mathrm{C}$ to obtain a soluble fraction $\left(\mathrm{S}_{12}\right)$. Five $\mathrm{ml}$ of $\mathrm{S}_{12}$ fraction was centrifuged at $150000 \times \mathrm{g}$ for $90 \mathrm{~min}$ at $4^{\circ} \mathrm{C}$ to obtain $\mathrm{S}_{150}$ fraction. The pellet fraction was washed twice with $0.2 \mathrm{M}$ phosphate buffer $(\mathrm{pH} 7.2)$ to remove soluble chromium reductase, if any and was resuspended in same buffer $(5 \mathrm{ml})$ to obtain membrane fraction $\left(\mathrm{P}_{150}\right)$. Equivalent volume of $\mathrm{S}_{12}, \mathrm{~S}_{150}$ and $\mathrm{P}_{150}$ fraction were assayed for studying the cellular localization of $\mathrm{Cr}(\mathrm{VI})$ reductase enzyme.

$\mathrm{Cr}(\mathrm{VI})$ reductase assay. $\mathrm{Cr}(\mathrm{VI})$ reductase activity of CFE was assayed following the procedure of Park et al. (2000). The reaction mixture $(1 \mathrm{ml})$ for the enzyme assay contained $0.2 \mathrm{mM} \mathrm{K}_{2} \mathrm{CrO}_{4}, 0.2 \mathrm{mM}$ NADH and $400 \mu 1$ of CFE in $0.2 \mathrm{M}$ phosphate buffer (pH 7.2). The reaction was stopped by adding $0.5 \mathrm{ml}$ of $20 \%$ trichloroacetic acid (Horitsu et al., 1987). Reduction of $\mathrm{Cr}(\mathrm{VI})$ was measured by estimating the decrease in $\operatorname{Cr}(\mathrm{VI})$ in the reaction mixture after $30 \mathrm{~min}$ of incubation at $35^{\circ} \mathrm{C}$ and quantified colorimetrically using 1,5-diphenylcarbazide as the complexing reagent (Urone, 1955). To eliminate the abiotic reduction of $\mathrm{Cr}(\mathrm{VI})$, if any, a control set was prepared through out the course of the study without putting any biotic component including bacterial cell. Whenever required, abiotic reduction of $\mathrm{Cr}(\mathrm{VI})$ has been subtracted from the total reduction to get the exact influence on chromium reduction by the biotic factors. Amount of protein in the CFE was estimated by the folin-phenol method (Lowry et al., 1951) using bovine serum albumin as the standard. One unit of $\mathrm{Cr}(\mathrm{VI})$ reductase activity was defined as the amount of enzyme which decreased $1.0 \mu \mathrm{M} \mathrm{Cr}(\mathrm{VI})$ per min at $35^{\circ} \mathrm{C}$. The effect of $\mathrm{pH}$ and temperature on $\mathrm{Cr}(\mathrm{VI})$ reductase were measured at different $\mathrm{pH}$ values (4 to 10.6 ) of the reaction mixture at $35^{\circ} \mathrm{C}$ and at different reaction temperature $\left(20\right.$ to $\left.100^{\circ} \mathrm{C}\right)$ at pH 7.2 respectively.

\section{Results and Discussions}

The reductase activities of the soluble fraction $\left(\mathrm{S}_{12}\right)$ from both the induced and uninduced cells of $B$. firmus KUCr1 were almost similar with regard to time course (Fig. 1). This study revealed that the chromate reductase in this strain is constitutive, which supports earlier reports on the enzymatic reduction of $\mathrm{Cr}(\mathrm{VI})$ under aerobic conditions (Bopp and Ehrlich, 1988; Campos et al., 1995; Wang and Xiao, 1995; McLean and Beveridge, 2001; Pal et al., 2005), though an inducible reductase in the soluble fraction of CFE of Ochrobactrum sp. was reported (Thacker and Datta, 2005). As the reductase activity was found to be constitutive, thus for further experiments CFE $\left(\mathrm{S}_{12}\right)$ was prepared from cells grown in $\mathrm{Cr}(\mathrm{VI})$-free medium for characterization of chromate reductase activity.

The effect of initial concentration of $\mathrm{Cr}(\mathrm{VI})$ on reductase activity of $\mathrm{S}_{12}$ fraction was determined at a concentration range of 0 to $80 \mu \mathrm{M}$ of $\mathrm{Cr}(\mathrm{VI})$. Specific activity increased with increasing initial concentration of chromate up to $40 \mu \mathrm{M}$, after that it slowed down but reduction continued (Fig. 2a) with enzyme equivalent to $0.493 \mathrm{mg}$ protein $/ \mathrm{ml}$. The saturation kinetics of $\mathrm{Cr}(\mathrm{VI})$ reduction of $\mathrm{S}_{12}$ fraction fit with the linearized Lineweaver-Burk plot, and the apparent Michaelis-Menten constant $\left(\mathrm{K}_{\mathrm{m}}\right)$ was found at $58.33 \mu \mathrm{M}$ chromate and $\mathrm{V}_{\text {max }}$ was $11.42 \mu \mathrm{M}$ per $\mathrm{min} / \mathrm{mg}$ protein (Fig. 2b). The $\mathrm{K}_{\mathrm{m}}$ and $\mathrm{V}_{\text {max }}$ values differed from the enzyme activity of the CFE of Bacillus sp. ES 29 (Camargo et al., 2003), B. subtilis (Garbisu et al., 1998), B. Sphaericus AND 303 (Pal et al., 2005), P. putida (Ishibashi et al., 1990; McLean and Beveridge

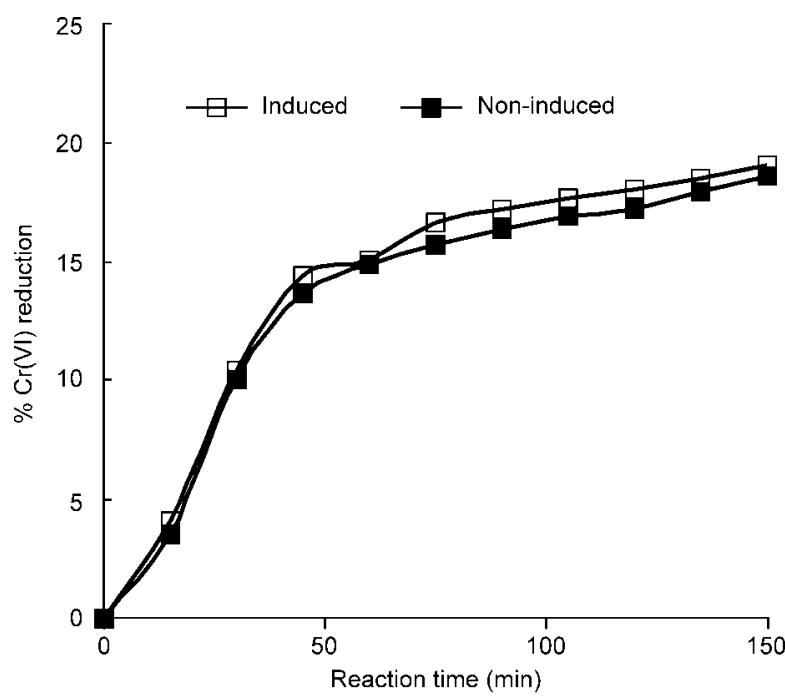

Fig. 1. $\mathrm{Cr}(\mathrm{VI})$ reduction by the extracts $\left(\mathrm{S}_{12}\right.$ from both induced [0.1 $\mathrm{mM} \mathrm{Cr}(\mathrm{VI})$ in the medium] and non-induced cells of B. firmus KUCr1. The reaction mixture contained $0.2 \mathrm{mM} \mathrm{Cr}(\mathrm{VI})$ and $0.2 \mathrm{mM}$ NADH as electron donor in $0.2 \mathrm{M}$ phosphate buffer $(\mathrm{pH} 7.2)$ and the reaction temperature was $35^{\circ} \mathrm{C}$. 

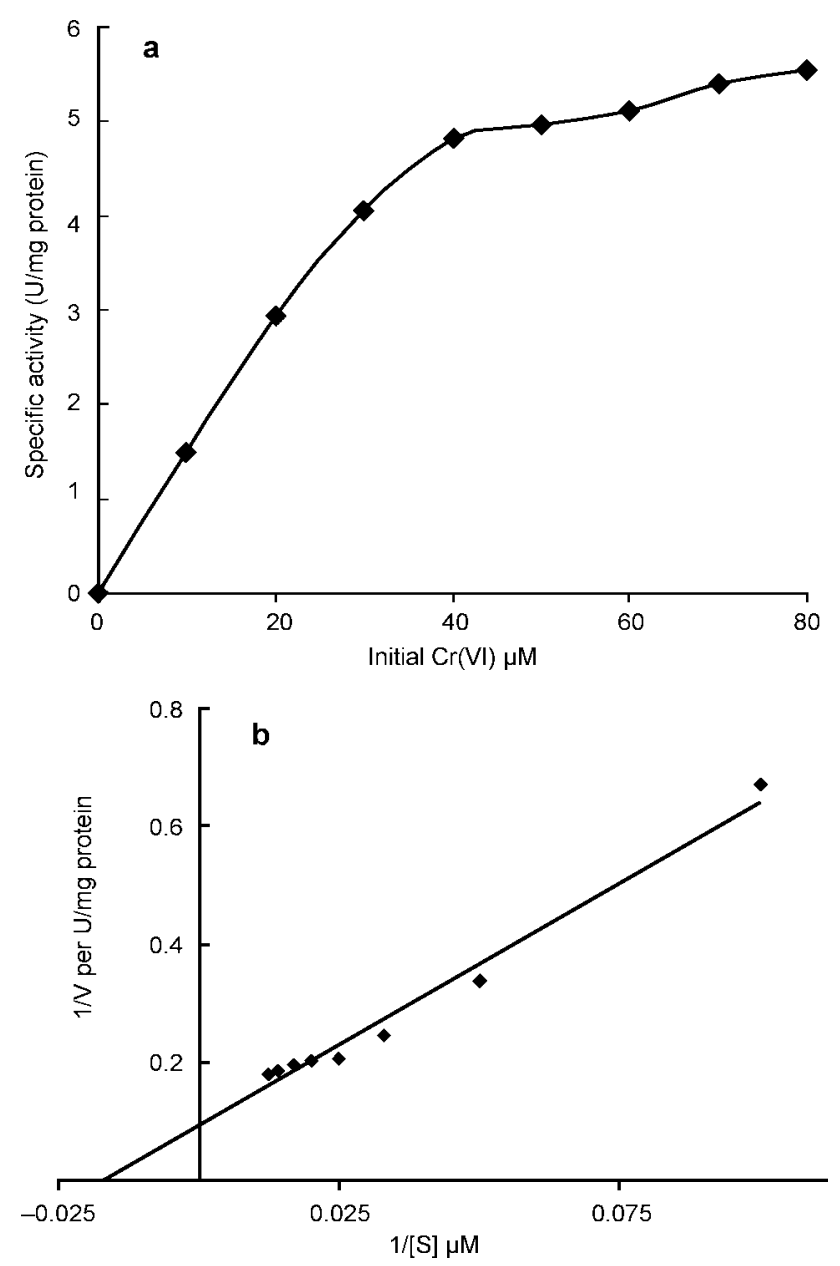

Fig. 2. Kinetics of $\mathrm{Cr}(\mathrm{VI})$ reduction of cell-free extract $\left(\mathrm{S}_{12}\right)$ of B. firmus $\mathrm{KUCr} 1$ at different $\mathrm{Cr}(\mathrm{VI})$ concentrations. Reaction time was $30 \mathrm{~min}$ at $35^{\circ} \mathrm{C}$ (a). Linearized Lineweaver-Burk plot for $\mathrm{Cr}(\mathrm{VI})$ reduction of cell-free extract $\left(\mathrm{S}_{12}\right)(\mathrm{b})$.

2001; Park et al., 2000) and in P. ambigua G-1 (Suzuki et al., 1992). Lower $\mathrm{K}_{\mathrm{m}}$ value of $\mathrm{Cr}(\mathrm{VI})$ reductase suggests higher affinity for the substrate, at least with what was found with the cell-free extract in this strain.

The effect of $\mathrm{pH}$ on reductase activity was assessed at a $\mathrm{pH}$ range of 4.0 to 10.6 using $0.2 \mathrm{M}$ of citrate buffer ( $\mathrm{pH} 4.0$ to 5.6), $0.2 \mathrm{M}$ of phosphate buffer ( $\mathrm{pH}$ 6.0 to 7.6$), 0.2 \mathrm{M}$ of tris- $\mathrm{HCl}$ buffer ( $\mathrm{pH} 8.4$ to 8.8 ) and $0.2 \mathrm{M}$ of glycine- $\mathrm{NaOH}$ buffer ( $\mathrm{pH} 9.2$ to 10.6 ) separately. The reductase activity achieved a maximum at pH 5.6 (Fig. 3). Similarly, the optimum temperature for highest $\mathrm{Cr}(\mathrm{VI})$ reduction was found at $70^{\circ} \mathrm{C}$ (Fig. 4). These results varied from other earlier reports with $B$. sphaericus AND 303, where they were $30^{\circ} \mathrm{C}$ and 6.0 respectively (Pal et al., 2005) and with P. putida MK1 (Park et al., 2000) or P. ambigua G-1 (Suzuki et al., 1992), the optimal temperature and $\mathrm{pH}$ being $80^{\circ} \mathrm{C}, 50^{\circ} \mathrm{C}$, and $\mathrm{pH} 5.0,8.6$ respectively.

The effect of electron donors, inhibitors and metal ions on chromate reduction by CFE $\left(\mathrm{S}_{12}\right)$ of $B$. firmus KUCr1 was determined. $0.2 \mathrm{mM}$ each of NADH, $\mathrm{NADPH}$, glutathion, D-glucose, and D-fructose were

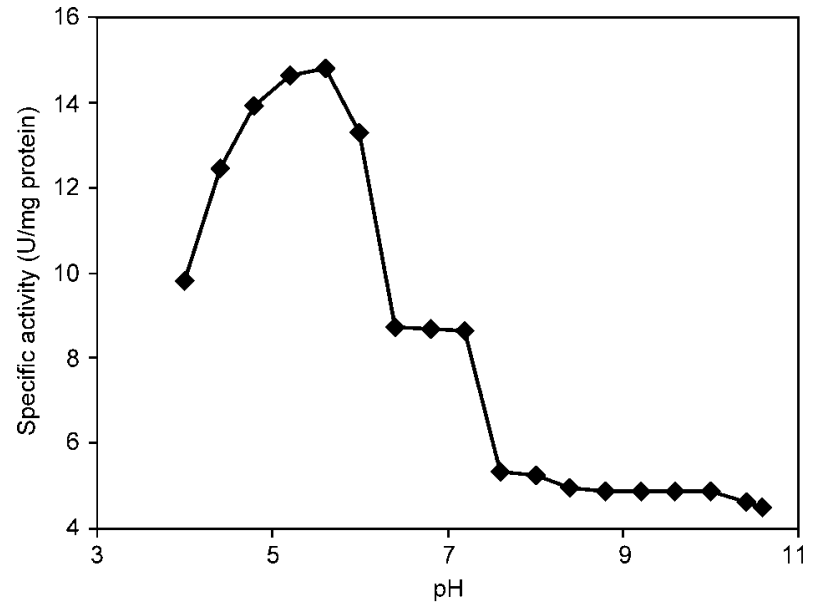

Fig. 3. Effect of $\mathrm{pH}$ on chromate reductase activity $\left(\mathrm{S}_{12}\right)$ of $B$. firmus $\mathrm{KUCr} 1$ at $35^{\circ} \mathrm{C}$ for $30 \mathrm{~min}$ of incubation.

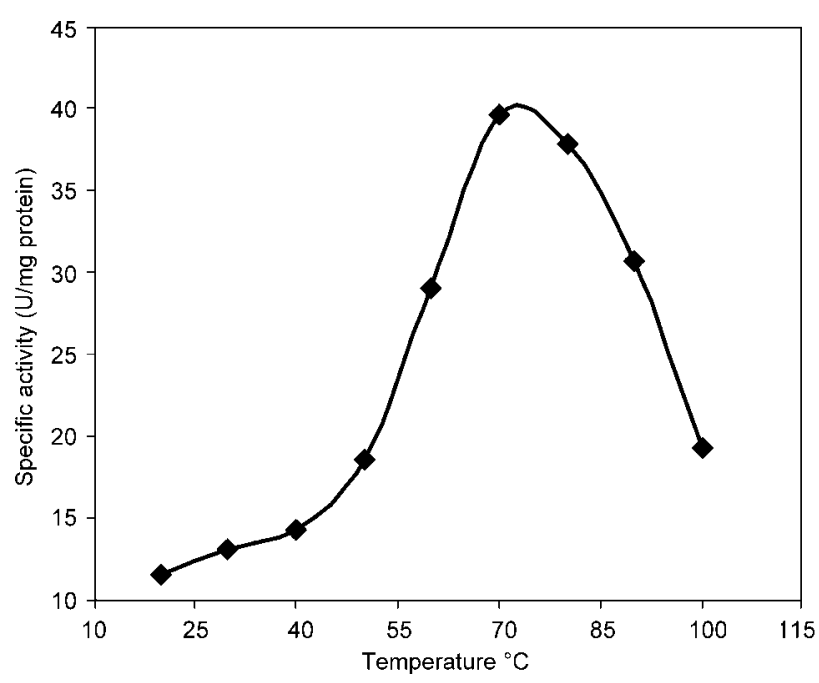

Fig. 4. Effect of temperature on chromate reductase activity $\left(\mathrm{S}_{12}\right)$ of $B$. firmus KUCr1. The assay was conducted in $0.2 \mathrm{M}$ phosphate buffer ( $\mathrm{pH}$ 7.2) for $30 \mathrm{~min}$.

used as electron donors. Among the electron donors used, only NADH showed a significant effect on chromate reductase activity ( $72 \%$ activity over control). NADPH gave $32 \%$ less activity than NADH (Table I).

Table I

Effect of electron donor on $\mathrm{Cr}(\mathrm{VI})$ reductase activity in cell-free extracts $\left(\mathrm{S}_{12}\right)$ of $B$. firmus $\mathrm{KUCr} 1$

\begin{tabular}{|l|c|c|}
\hline $\begin{array}{c}\text { Electron donor } \\
(0.2 \mathrm{mM})\end{array}$ & $\begin{array}{c}\text { Specific activity } \\
(\mathrm{U} / \mathrm{mg} \text { protein) }\end{array}$ & $\begin{array}{c}\text { Relative specific } \\
\text { activity }^{\mathrm{b}}(\%)\end{array}$ \\
\hline None (control) & $2.40( \pm 0.01)$ & 27.74 \\
\hline NADH & $8.65( \pm 0.06)$ & 100.00 \\
\hline NADPH & $5.87( \pm 0.08)$ & 67.86 \\
\hline Glutathione & $2.53( \pm 0.02)$ & 29.24 \\
\hline D-glucose & $2.89( \pm 0.01)$ & 33.41 \\
\hline D-fructose & $2.70( \pm 0.07)$ & 31.21 \\
\hline
\end{tabular}

${ }^{a}$ Data are the mean of three replications plus standard error. The reaction mixture contained $0.2 \mathrm{mM} \mathrm{Cr}(\mathrm{VI})$ in $0.2 \mathrm{M}$ phosphate buffer $\left(\mathrm{pH} \mathrm{7.2)}\right.$ and was incubated for $30 \mathrm{~min}$ at $35^{\circ} \mathrm{C}$.

b $\left.\{\text { (Specific activity) / (specific activity })_{\mathrm{NADH}}\right\}$ X 100 


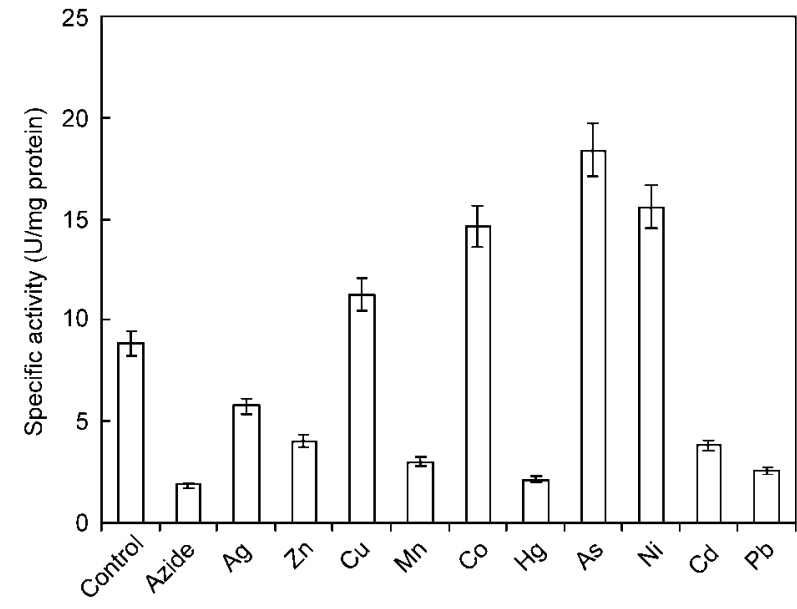

Fig. 5. Effect of azide $\left.\left(\mathrm{NaN}_{3}, 0.2 \mathrm{mM}\right)\right)$ and some selected metals $(0.2 \mathrm{mM})$ on $\mathrm{Cr}(\mathrm{VI})$ reductase activity in the cell-free extracts $\left(\mathrm{S}_{12}\right)$ of $B$. firmus $\mathrm{KUCr} 1$. Data are the mean of three replications with error bars.

In the presence of glutathion, D-glucose, and D-fructose, the non-enzymatic reductants of $\mathrm{Cr}(\mathrm{VI})$, the activity of the reductase was almost equal to that of the control.

The cell-free enzyme of $B$. firmus KUCr1 required $\mathrm{NADH}$ or NADPH as an electron donor for better enzymatic $\mathrm{Cr}(\mathrm{VI})$ reduction. The reductase became sharply more active in the presence of NADH than $\mathrm{NADPH}$, suggesting the requirement of a cofactor for catalytic activity. NADH dependent $\mathrm{Cr}(\mathrm{VI})$ reduction was also advocated by several researchers earlier in Bacillus (Garbisu et al., 1998; Camargo et al., 2003) and in Pseudomonas (Suzuki et al., 1992; Park et al., 2000). Our study also supports the earlier observations on the role of nonenzymatic reductants like glutathione, D-glucose and D-fructose on $\mathrm{Cr}(\mathrm{VI})$ reduction by CFE (Branca et al., 1990; Shi and Dalal, 1990; Suzuki et al., 1992).

$\mathrm{Cr}(\mathrm{VI})$ reduction by CFE was significantly inhibited in the presence of $0.2 \mathrm{mM}$ sodium azide (Fig. 5). The metal cations, $\mathrm{Ag}^{+}, \mathrm{Zn}^{2+}, \mathrm{Cd}^{2+}, \mathrm{Pb}^{2+}, \mathrm{Mn}^{2+}$, and $\mathrm{Hg}^{2+}$ inhibited reductase activity by more than $50 \%$ over the control in the reaction mixture (Fig. 5). However, $\mathrm{Co}^{2+}, \mathrm{Ni}^{2+}, \mathrm{As}^{3+}$ and $\mathrm{Cu}^{2+}$ stimulated the activity of CFE. The order of stimulation by these metal cations in reductase activity was found to be $\mathrm{As}^{3+}>\mathrm{Ni}^{2+}$ $>\mathrm{Co}^{2+}>\mathrm{Cu}^{2+}$.

In this study, $\mathrm{Cr}(\mathrm{VI})$ reductase activity was found to be inhibited by a respiratory inhibitor, sodium azide $(0.2 \mathrm{mM})$. Though chromate reductase in CFE was reported to be unaffected by azide in Escherichia coli ATCC 33456 (Shen and Wang, 1993), Bacillus sp. ES29 (Camargo et al., 2003) and in B. megaterium TKW3 (Cheung et al., 2006) by $1.0 \mathrm{mM} \mathrm{NaN}_{3}$. However, inhibition of $\mathrm{Cr}(\mathrm{VI})$ reduction due to $\mathrm{NaN}_{3}$ in live cells of a Bacillus subtilis strain was reported (Garbisu et al., 1998). Inhibition of a cytoplasmic membrane associated $\mathrm{Cr}(\mathrm{VI})$ reductase by azide was also reported in Shewanella putrefaciens MR-1 (Myers et al., 2000). The interference of azide in $\mathrm{Cr}(\mathrm{VI})$ reduction in this study and views from earlier reports suggest the possible coexistence of $\mathrm{Cr}(\mathrm{VI})$ reductase in the cytosol and membrane as well. However, further investigations are required to elucidate this particular feature.

The cations $\mathrm{Hg}^{2+}$ and $\mathrm{Ag}^{+}(0.2 \mathrm{mM})$ inhibited reductase activity. The noncompetitive inhibitory effect of $\mathrm{Hg}^{2+}$ and $\mathrm{Ag}^{+}$on $\mathrm{Cr}(\mathrm{VI})$ reduction in P. putida was reported earlier (Ishibashi et al., 1990). The inhibitory effect of $\mathrm{Hg}^{2+}$ is expected, because of its affinity for ligands containing thiol (-SH) group of a variety of enzymatic proteins. Enzymatic reduction of $\mathrm{Cr}(\mathrm{VI})$ by CFE of $B$. firmus $\mathrm{KUCr} 1$ was stimulated by $\mathrm{Cu}^{2+}$, $\mathrm{As}^{3+}, \mathrm{Ni}^{2+}$ and $\mathrm{Co}^{2+}$ at $0.2 \mathrm{mM}$ concentration separately, though Pal et al. (2005) reported the inhibition of $\mathrm{Cr}(\mathrm{VI})$ reductase activity of $B$. sphaericus AND 303 by $\mathrm{Ni}^{2+}$ and $\mathrm{Co}^{2+}$ at $100 \mu \mathrm{M}$ concentration. The reductase activity was found to be unaffected by $\mathrm{As}^{3+}$ in P. putida MK1 (Park et al., 2000). Stimulation of enzyme activity by $\mathrm{Cu}^{2+}$ might be due to its nature as a prosthetic group of many reductase enzymes and also indirectly involved in the protection of chromate reductase from $\mathrm{O}_{2}$, for oxygen-sensitive enzyme (Ettinger 1984; Camargo et al., 2003). Abe et al. (2001) reported that $\mathrm{Cu}^{2+}$ acting as electron-transport protection or acting as a single electron redox center and as a shuttle for electron between protein subunits. $\mathrm{Zn}^{2+}, \mathrm{Cd}^{2+}$, $\mathrm{Pb}^{2+}$ and $\mathrm{Mn}^{2+}$ inhibited the reductase activity at $0.2 \mathrm{mM}$. Inhibitory effects by $\mathrm{Cd}^{2+}$ and $\mathrm{Zn}^{2+}$ support the earlier views (Park et al., 2000; Pal et al., 2005; Desai et al., 2008). On the contrary, Camargo et al. (2003) showed slight stimulatory effect of $\mathrm{Mn}^{2+}$ on $\mathrm{Cr}(\mathrm{VI})$ reductase in Bacillus sp. ES 29. These variations seem to be due to the different functional nature of the $\mathrm{Cr}(\mathrm{VI})$ reductase in B. firmus $\mathrm{KUCr}$, which warrants further investigation.

$\mathrm{Cr}(\mathrm{VI})$ reductase activities by different cellular fractions are presented in Table II. In the presence of electron donor $(0.2 \mathrm{mM} \mathrm{NADH}) \mathrm{S}_{150}$ fraction showed higher activity than fractions $\mathrm{S}_{12}$ and $\mathrm{P}_{150}$.

Table II

Localization of $\mathrm{Cr}(\mathrm{VI})$ reductase in cell fractions of $B$. firmus $\mathrm{KUCr} 1$ and its catalytic activity

\begin{tabular}{|l|c|c|}
\hline $\begin{array}{l}\text { Cellular } \\
\text { fraction }^{\text {a }}\end{array}$ & $\begin{array}{c}\text { \% Cr(VI) } \\
\text { reduction }^{\text {b }}\end{array}$ & $\begin{array}{c}\text { Specific activity } \\
\text { (U/mg protein) }\end{array}$ \\
\hline $\mathrm{S}_{12}$ & 14.21 & $9.12( \pm 0.03)$ \\
\hline $\mathrm{S}_{150}$ & 15.66 & $14.68( \pm 0.04)$ \\
\hline $\mathrm{P}_{150}$ & 6.98 & $7.34( \pm 0.04)$ \\
\hline
\end{tabular}

a $\mathrm{S}$ stands for soluble cellular fractions and $\mathrm{P}$ stands for membrane fractions (see Materials and Methods).

b Reaction mixture contained $0.2 \mathrm{mM} \mathrm{Cr}(\mathrm{VI})$ in phosphate buffer $(\mathrm{pH}$ 7.2) and was incubated for $30 \mathrm{~min}$ at $35^{\circ} \mathrm{C}$.

Data are the mean of three repetitions plus standard error. 
The percentage of $\mathrm{Cr}(\mathrm{VI})$ reduction by fraction $\mathrm{P}_{150}$ is significantly less compared to other fractions, but the specific activity signifies its catalytic function, suggesting the occurrence of some membrane-bound protein responsible for $\mathrm{Cr}(\mathrm{VI})$ reduction. In Bacillus QC1-2 (Campos et al., 1995), B. sphaericus AND 303 (Pal et al., 2005) and P. putida (Ishibashi et al., 1990; Park et al., 2000) the chromium reductase activities were reported to be associated with the cytosolic and soluble fractions. In Enterobactor cloacae (Wang et al., 1990), S. putrefaciens MR-1 (Myers et al., 2000), B. megaterium TKW3 (Cheung et al., 2006) and P. fluorescences (Bopp and Ehrlich, 1988) Cr(VI) reductase appears to be membrane associated. Lovley and Phillips (1994) reported that both the soluble and membrane fractions reduced chromate in Desulfovibrio vulgaris but soluble protein fraction reduced $\mathrm{Cr}(\mathrm{VI})$ faster than the membrane fraction did. In Bacillus cereus S-6 (Iftikhar et al., 2007) Cr(VI) reduction occur both in cytosolic and membrane fraction of this strain but percentage of reduction in cytosolic fraction is higher than membrane fraction. It seems that KUCr1 harbors $\mathrm{Cr}(\mathrm{VI})$ reductase constitutively both in membrane and cytosol. Thus further investigations to visualize the exact pathway of $\mathrm{Cr}(\mathrm{VI})$ reduction in this particular strain are required.

Enzyme inhibition by respiratory inhibitors like $\mathrm{NaN}_{3}$ and $\mathrm{Cr}(\mathrm{VI})$ reductase activity by the $\mathrm{P}_{150}$ fraction suggest the co-existence of a membrane-bound, respiratory-chain-linked reductase activity in this strain; study with purified proteins of both the cytosolic and membrane fractions would provide more knowledge about the exact pathway of $\mathrm{Cr}(\mathrm{VI})$ in this particular strain. Moreover, the feature of higher temperature optima of $\mathrm{Cr}(\mathrm{VI})$ reductase of the cytosolic soluble fraction in $\mathrm{KUCr} 1$ suggests the possibility to clone the gene into a thermophilic bacteria, so that it could offer a decisive advantage in chromium bioremediation under conditionally elevated temperature or in a bioreactor system using immobilized enzyme.

\section{Acknowledgement}

This work was supported by the grant received from the University of Kalyani, India.

\section{Literature}

Abe F., T. Miura, T. Nagahama, A. Inoue, R. Usami and K. Horikoshi. 2001. Isolation of a highly copper-tolerant yeast, Cryptococcus sp., from the Japan trench and the induction of superoxide dismutase activity by $\mathrm{Cu}^{2+}$. Biotechnol. Lett. 23: 2027-2034. Bopp L.H. and H.L. Ehrlich. 1988. Chromate resistance and reduction in Pseudomonas fluorescens strain LB300. Arch. Microbiol. 150: 426-431.

Branca M., A. Dessi, H. Koziowsi, G. Micera and J. Swiatek. 1990. Reduction of chromate ions by glutathione tripeptide in the presence of sugar ligands. J. Inorg. Biochem. 39: 217-226.
Camargo F.A.O., B.C. Okeke, F.M. Bento and W.T. Frankenberger. 2003. In vitro reduction of hexavalent chromium by a cellfree extract of Bacillus sp. ES29 stimulated by Cu. Appl. Microbiol. Biotechnol. 62: 569-573.

Campos J., M. Martinez-Pacheco and C. Cervantes. 1995. Hexavalent-chromium reduction by a chromate-resistant Bacillus sp. strain. Antonie van Leeuwenhoek 68: 203-208.

Cervantes C., J.C. Garcia, S. Devars, F.G. Corona, H.L. Tavera, J.C. Guzman and R.M. Sanchez. 2001. Interactions of chromium with microorganisms and plants. FEMS Microbiol. Rev. 25: 335-347.

Cheung K.H. and J.D. Gu. 2007. Mechanism of hexavalent chromium detoxification by microorganisms and bioremediation application potential: A review. Int. Biodet. Biodegrad. 59: 8-15. Cheung K.H., H.Y. Lai and J.D. Gu. 2006. Membrane-associated hexavalent chromium reductase of Bacillus megaterium TKW3 with induced expression. J. Microbiol. Biotechnol. 16, 855-862.

Desai C., J. Kunal and M. Datta. 2008. Hexavalent chromate reductase activity in cytosolic fractions of Pseudomonas sp. G1DM21 isolated from $\mathrm{Cr}(\mathrm{VI})$ contaminated industrial landfill. Process Bichem. 43: 713-721.

Ettinger M.J. 1984. Copper metabolism and diseases of copper metabolism. pp. 175-230. In: R. Lontie (ed). Copper Proteins and Copper Enzymes. CRC, Boca Raton.

Ganguli A. and A.K. Tripathi. 2002. Bioremediation of toxic chromium from electroplating effluent by chromate-reducing Pseudomonas aeruginosa A2Chr in two bioreactors. Appl. Microbiol. Biotechnol. 58: 416-420.

Garbisu C., I. Alkorta, M.J. Llama and J.L. Serra. 1998. Aerobic chromate reduction by Bacillus subtilis. Biodegrad. 9: 133-141. Horitsu H., S. Futo, Y. Miyazawa, S. Ogai and K. Kawai. 1987. Enzymatic reduction of hexavalent chromium by hexavalent chromium tolerant Pseudomonas ambigua G-1. Agric. Biol. Chem. 51: 2417-2420.

Iftikhar S., M. Faisal and S. Hasnain. 2007. Cytosolic reduction of toxic $\mathrm{Cr}(\mathrm{VI})$ by indigenous microorganism. Res. J. Env. Sci. 1: 77-81.

Ishibashi Y., C. Cervantes and S. Silver. 1990. Chromium reduction in Pseudomonas putida. Appl. Environ. Microbiol. 56 2268-2270.

Losi M.E., C. Amrhein and W.T. Frankenberger. 1994. Environmental biochemistry of chromium. Rev. Environ. Contam. Toxicol. 36: 91-121.

Lovley D.R. and E.J.P. Phillips. 1994. Reduction of chromate by Desulfovibrio vulgaris and its $c_{3}$ cytochrome. Appl. Environ. Microbiol. 60: 726-728.

Lowry O.H., N.J. Resebrough and A.L. Farr. 1951. Protein measurement with the folin-phenol reagent. J. Biol. Chem. 193: 265-275.

McLean J. and T.J. Beveridge. 2001. Chromate reduction by a pseudomonad isolated from a site contaminated with chromated copper arsenate. Appl. Environ. Microbiol. 67: 1076-1084.

Myers C.R., B.P. Carstens, W.E. Antholine and J.M. Myers. 2000. Chromium (VI) reductase activity is associated with the cytoplasmic membrane of anaerobically grown Shewanella putrifaciens MR-1. J. Appl. Microbiol. 88: 98-106.

Ohtake H. and S. Silver. 1994. Bacterial detoxification of toxic chromate. pp. 403-415. In: G.R. Choudhuri (ed). Biological Degradation and Bioremediation of Toxic Chemicals. Discorides Press, Portland.

Pal A., S. Dutta and A.K. Paul. 2005. Reduction of hexavalent chromium by cell-free extract of Bacillus sphaericus AND 303 isolated from serpentine soil. Curr. Microbiol. 66: 327-330.

Park C.H., B. Keyhan, B. Wielinga, S. Fendorf and A. Matin. 2000. Purification to homogeneity and characterization of a novel 
Pseudomonas putida chromate reductase. Appl. Environ. Microbiol. 66: 1788-1795.

Sau G.B., S. Chatterjee, S. Sinha and S.K. Mukherjee. 2008 Isolation and characterization of a $\mathrm{Cr}(\mathrm{VI})$ reducing Bacillus firmus strain from industrial effluents. Polish J. Microbiol. 57: 327-332.

Shakoori A.R., S. Tahseen and R.U. Haq. 1999. Chromiumtolerant bacteria isolated from industrial effluents and their use in detoxification of hexavalent chromium. Folia Microbiol. 44 $50-54$.

Shen H. and Y.T. Wang. 1993. Characterization of enzymatic reduction of hexavalent chromium by Escherichia coli ATCC 33456. Appl. Environ. Microbiol. 59: 3771- 3777.

Shi X. and N.S. Dalal. 1990. On the hydroxyl radical formation in the reaction between hydrogen peroxide and biologically generated chromium(V) species. Arch. Biochem. Biophys. 277: $342-350$

Suzuki T., N. Miyata, H. Horitsu, K. Kawai, K. Tsakamizawa, Y. Tai and M. Okazaki. 1992. NAD(P)H dependent chromium (VI) reductase of Pseudomonas ambigua G-1: A $\mathrm{Cr}(\mathrm{V})$ inter- mediate is formed during the reduction of $\mathrm{Cr}(\mathrm{VI})$ to $\mathrm{Cr}(\mathrm{III})$. J. Bacteriol. 174: 5340-5345.

Thacker U. and M. Datta. 2005. Reduction of toxic chromium and partial localization of chromium reductase activity in bacterial isolate DM1. World J. Microbiol. Biotechnol. 21: 891-899.

Urone F.E. 1955. Stability of colorometric reagent for chromium. S-diphenylcarbazides in various solvents. Anal. Chem. 27: 13541355.

Wang P.C., T. Mori, K. Toda and H. Ohtake. 1990. Membrane associated chromate reductase activity from Enterobactor cloacae. J. Biotechnol. 172: 1670-1672.

Wang Y.T. and C. Xiao. 1995. Factors affecting hexavalent chromium reduction in pure cultures of bacteria. Water Res. 29: 2467-2474.

Xu X.R., H.B. Li and J.D. Gu. 2004. Reduction of hexavalent chromium by ascorbic acid in aqueous solutions. Chemosphere 57: 609-613.

Xu X.R., H.B. Li, J.D. Gu and X.Y. Li. 2005. Kinetics of the reduction of chromium (VI) by vitamin C. Environ. Toxicol. Chem. 24: 1310-1314. 